\title{
What passes in Imitation of Life (1959)?
}

MONIQUE ROONEY

You can't escape what you are. ${ }^{1}$

The above epigraph comes from Jon Halliday's well-known interview with Douglas Sirk, the director of Imitation of Life (1959), and is made in reference to the condition of the racial passer in Sirk's film. It could be said that Sirk's line encapsulates the conservative and essentialist nature of passing-for-white stories in which the mixed-race character's transgressive desire to escape her origins typically ends in the death of her 'false' (because passing) identity. Typically, in such stories, the passer either returns to her authentic identity (her pre-passing life) or is killed off in a melodramatic story that ultimately upholds social or ideological conventions. Undercutting the didacticism of Sirk's remark, however, is the visual veracity of Imitation of Life's passer, Sarah Jane. Played by the Mexican-American actor Susan Kohner, Sarah Jane looks like the white girl who, throughout the film, she repeatedly says she wants and believes herself to be. The implication of Sirk's statement, if understood in the light of Sarah Jane's white-looking appearance, is that who we are is not necessarily how we look. In other parts of the interview - in which he discusses his theatre-directing and film-making career-Sirk both reinforces and challenges ontological assumptions that equate seeing with being. This is especially the case when he states that the camera sees things that the human eye cannot. Sirk's reasoning about who and what Sarah Jane is, what she passes as, can be understood not simply in terms of the director's philosophical understanding of the visual field but in terms of the mechanical, non-human, non-subjective view of the camera lens. As I will show in what follows, the performances of key actors/ characters also exceed Sirk's prescriptive statement given that what his film points to is the primacy of the body as visual spectacle. ${ }^{2}$ In considering 'what passes in Imitation of Life', this essay highlights the ways in which Imitation of Life, on the one hand, knowingly replays melodramatic conventions and orthodoxies. On the other hand, it is a film that draws attention to the visual presentation of the expressive body. This body is axiomatic to melodrama, to

1 Douglas Sirk in Halliday, Jon 1997, Sirk on Sirk: Conversations with Jon Halliday, Faber \& Faber, London, p. 148.

2 For discussion of the primacy of the image - to the point where the plot seems secondary to costuming and mise en scène - see Paul Willemen's famous essay 'Towards an analysis of the Sirkian system' (in Fischer, Lucy [ed.] 1991, Imitation of Life: Douglas Sirk, director, Rutgers University Press, New Brunswick, NJ, pp. 273-8). 
passing narratives and to understandings of subjectivity itself. Imitation of Life, I argue, is a film in which the complexity of the body-especially when viewed through the mechanical lens of the camera- has the capacity to pass unnoticed. In this way, Imitation of Life can be understood as a Hollywood narrative that reminds spectators of the primary importance of the 'seen' at the same time as it dramatises the productive failure or expressive gaps in the medium.

In what follows, therefore, I analyse what the melodramatic passing plot conceals as much as what it exposes. The passing-for-white story is - as Sirk claims in no uncertain terms - essential to the film's overall meaning. In the first section, drawing on Sirk's commentary about film-making and production, I connect the racial-passing theme with what the film communicates about cinema as a primarily visual narrative form. Sirk's discussion of the technological apparatus of film-making and his self-reflexive views on what it means to direct, especially his awareness of the difference between what he says about film-making and what his films present, suggest that what passes on screen falls outside the limits of his own, directorial vision. That is - in tension with Sirk's statement that there is a Sarah Jane who exists prior to her passing self, that is before she attempts to escape who she is - her cinematic subjectivity is constituted through the mechanical lens that presents her as white. Recognition of what passes in Imitation therefore demands a consideration of how the camera presents bodies on screen. In Imitation of Life, the subjectivity of these bodies is rendered visible through categorical determinants (sex as well as race) that can only partially account for human presence. The role of the film's underacknowledged producer, Ross Hunter, becomes significant here, especially the part he played in casting actors who were passing for straight (most notably, Rock Hudson). ${ }^{3}$ Sirk makes two enigmatic references to Ross Hunter in the 1997 reprint of Sirk on Sirk: Conversation with Jon Halliday. For the original publication of this interview (1971), Sirk had asked that Halliday refrain from publishing comments he made about Ross Hunter's homosexuality until after Hunter's death. In the republished interview (1997), Sirk effectively outed Ross Hunter's, and his protégé Rock Hudson's, homosexuality. In this first section, I show how Sirk's stated ambivalence about his producer-especially Hunter's relationship to Hollywood actors - is doubled through the film's representation of Lana Turner as, what Sirk calls, the film's 'cheap commodity', its 'false creation'.

\footnotetext{
3 For discussion of Rock Hudson and homosexual passing, see Klinger, Barbara 1994, ‘Rock Hudson and the burdens of masculinity', Melodrama and Meaning: History, culture and the films of Douglas Sirk, Indiana University Press, Bloomington and Indianapolis, pp. 97-131. See also: Kashner, Sam and MacNair, Jennifer 2002, 'The artist and "Charlie movie star": Douglas Sirk and the making of Rock Hudson', The Bad and The Beautiful: Hollywood in the Fifties, W. W. Norton, New York, pp. 139-55; Stagg, Sam 2009, 'The business of glamoo', Born To Be Hurt: The untold story of Imitation of Life, St Martins Press, New York.
} 
In the second section, I connect Sirk's reading of Hunter's influence on Hudsonwhich can be understood as a queer-passing-for-straight plot - with uncanny parallels in Imitation's (racial) passing story. ${ }^{4}$ The film stages racial passing as an oedipal family romance when Sarah Jane betrays her mother and follows in her surrogate mother's footsteps to become a 'white' actress. In attending to the gap between the stated views of Imitation's director and what the film screenswhat passes in Imitation of Life - the third section of this essay analyses the film's more obvious, passing-for-white drama in terms of its less spectacular plot about the intimate relationship between a black and a white woman. In this third section, I connect the spectacle of Sarah Jane's passing with the ambivalent desires of Lora Meredith (her surrogate mother) and her conflicted love for her maid (Annie). The charged, interracial intimacy between these two women, who share a home and parent one another's children, is integral to Sarah Jane's desire to pass and can also be understood as a passing narrative. The passing of this female-female bond - as Sirk suggests in interview - is partly to do with Lora's blindness to the limitations of her ambitious dreams. Repeating Lora's ambition, and wanting to escape a black identity that feels more like a stereotype than a proper, or at least empowered, subjective position, Sarah Jane passes and, again mirroring Lora, does not herself recognise her love for Annie until the point of her death.

\section{Imitation's director and producer}

Imitation's director, Douglas Sirk—a German émigré whose most famous films were made with producer Ross Hunter for Universal Studios between 1950 and 1959 - speaks eloquently about the role of Imitation's racial passer, Sarah Jane, and makes connections between her and the 'restless' or 'split' character that he insists is so central to his cinematic oeuvre. Imitation of Life intertwines the lives of two different sets of characters that, placed in the same house, would normally be separated by race. Sarah Jane and her mother, Annie Johnson (Juanita Moore), live with a budding stage and screen actress who has taken the destitute pair in to her home. Lana Turner stars as the white mother (Lora Meredith) in a parallel story about mother/daughter conflict in which Lora's only child, Susie (Sandra Dee), resents her mother's narcissistic ambition. In the interview with Jon Halliday in which he discusses Imitation's twin plots, Sirk disparages the 'white' storyline, the one that features the film's star:

\footnotetext{
4 In another parallel, Ross Hunter sought permission from his friend Fannie Hurst to film her original novel Imitation of Life (1933). See Rooney, Monique 2010, 'My you: Fannie Hurst, Zora Neale Hurston and literary patronage', Working Papers on the Web, Special issue: Racial Disciplines, viewed 4 February 2010, <http:// extra.shu.ac.uk/wpw/race/introd.htm>, which reads Hurst's relationship to her protégé, Zora Neale Hurston, via the passing thematics of her novel. The Hurst/Hurston duo has uncanny parallels with the Hunter/Hudson friendship.
} 
The only interesting thing is the Negro angle: the Negro girl trying to escape her condition, sacrificing to her status in society her bonds of friendship, family etc., and rather trying to vanish into the imitation world of vaudeville. The imitation of life is not the real life. Lana Turner's life is a very cheap imitation. The girl [Susan Kohner] is choosing the imitation of life instead of being a Negro. The picture is a piece of social criticism - of both black and white. You can't escape what you are...

I tried to make it into a picture of social consciousness - not only of a white social consciousness, but of a Negro one, too. Both white and black are leading imitated lives... There is a wonderful expression: seeing through a glass darkly. Everything, even life, is inevitably removed from you. You can't reach, or touch, the real. You just see reflections. If you try to grasp happiness itself your fingers only meet glass. It's hopeless. ${ }^{5}$

Elsewhere, Sirk insists it is only this 'split' character type that interests him. ${ }^{6}$ Sirk enigmatically states that it is the 'restless, moving energy' of this figure that captures his attention and is central to his cinema dramas. As Sirk himself stated in interview, ${ }^{7}$ and as Elizabeth Bronfen recently argued in her Freudian reading of the film, ${ }^{8}$ this character played out a drama of irrecoverable loss that haunted Sirk throughout his career. A German Jew, who anglicised his original name, Dietlef Sierk, Sirk was separated from his son after his ex-wife-turned-Nazi banned Sirk from having any contact with him. Several years after his move to the United States, Sirk returned to Germany but failed in his attempt to find his son. His only contact with the boy, who was for a time a child actor, was by viewing him onscreen.

In other parts of the interview, however, Sirk argued that what drove his repeated melodramas that featured this character type was also his interest in narrative. He draws attention to a classic narrative structure - the deus ex machina - in order to emphasise the tensions between his directorial interest in crossing (the restless movement of the 'split' character or passer) as a form of 'social criticism' and the necessity that he comply with Hollywood genres and conventions. The following is worth quoting at length for it articulates a dramatic structure that forms the basis of many of his films and, in particular relation to Imitation of Life, facilitates his screening of a multilayered, passing, story. Elaborating on his interest in the French term échec (literally meaning blocked, no exit), Sirk draws attention to how melodrama can simultaneously expose and conceal its own intentions:

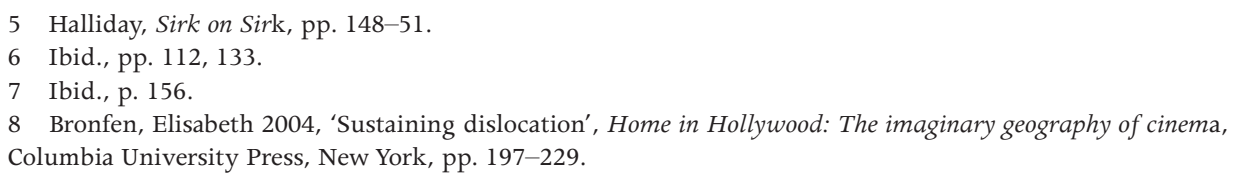


I'm not interested in failure in the sense given it by the neo-romantics who advocate the beauty of failure. It is rather the kind of failure which invades you without rhyme or reason - not the kind of failure you can find in a writer like Hofmannsthal. In both Written on the Wind and The Tarnished Angels it is an ugly kind of failure, a completely hopeless one. And this, again, is why the concept of échec is so good: there is no exit. All the Euripidean plays have this no exit - there is only one way out, the irony of the 'happy ending'. Compare them with the American melodrama. There, in Athens, you feel an audience that is just as happygo-lucky as the American audience, an audience that doesn't want to know that they could fail. There's always an exit. So you have to paste on a happy ending. The other Greek tragedians have it, but with them it is combined with religion. In Euripides you see his cunning smile and his ironic twinkle.

That is where the flashback comes in. In Written on the Wind, as in Summer Storm, you start with an end situation. The spectator is supposed to know what is waiting for him. It is a different type of suspense, or anti-suspense. The audience is forced to turn its attention to the how instead of the what - to structure instead of plot, to variations of a theme, to deviations from it, instead of the theme itself. This is what I call the Euripidean manner. And at the end there is no solution of the antitheses, just the deus ex machina, which today is called the 'happy ending ${ }^{\prime} \cdot{ }^{9}$

Sirk's linking of the populist Hollywood form to a classic tradition reaching back to Euripides was telling in relation to the films he made for Universal Pictures - an oeuvre that he himself stated was part melodrama, part ironic 'social criticism'. Sirk's reading of melodrama here is of a form with a rich, intellectual history that, he also insists, is necessarily formulaic (that is, it is a genre driven towards the 'happy ending') and open to multiple readings (that is, Sirk's comment that the audience is expected to turn attention to the hidden meaning - the how instead of the what - implies that the director deliberately plays with audience expectation and sets up an open-ended conclusion). Ironically, however, in other parts of the Halliday interview, Sirk dismisses some of the most formulaic elements of his melodramas, as well as his use of Hollywood stars such as Lana Turner and Rock Hudson who, unlike the restless passer, are described as cheap imitations or frozen caricatures. As if undercutting his reading of melodrama as Euripidean, and his association of American with Athenian audiences, Sirk states that his compliance with Hollywood forms - including casting stars - is just an act of empty commodification. Compromise with the Hollywood dream machine was a necessary evil, Sirk implied, that enabled him to smuggle in

9 Halliday, Sirk on Sirk, pp. 133-6. 
more controversial content. The double meaning of his film All That Heaven Allows (1954) speaks directly to Sirk's love of both cliché and its failure - that is, cliché's opposite. 'The studio loved this title,' Sirk told Halliday, 'they thought it meant you could have everything you wanted. I meant it exactly the other way round. As far as I am concerned, heaven is stingy.' ${ }^{\prime 0}$

The narrative logic that Sirk here uncovers - one that allows for different kinds of reading and that contains but also conceals its more radical elements - is also a feature of passing narratives. Passing stories, as I have argued elsewhere, articulate socio-cultural conditions but also the possibilities and limits (the échec) of narrating or representing a socially transgressive identity. The passing narrative's dramatisation and punishment of a potentially dangerous social crossing point to the contingent, and necessarily unstable, nature of all narrative or meaning-making processes. ${ }^{11}$ In this way, I argue, stories of passing articulate how narrative is conditioned by the lived reality on which it is based. At the same time, the passing story draws attention to the artificiality of its own narrative formula as one that raises the possibility of social transgression but ultimately capitulates to the set of ideologies or social rules that shape it. It has often been argued that stories of passing, while potentially transgressive in that they enable questioning of the 'status quo', ${ }^{12}$ are ultimately conservative in their conformity to social and aesthetic scripts. The subversive possibilities of passing are numerous - as a crossing of too-rigid borders, such as the 'color line' in the pre-civil rights United States; passing can provide relief from oppression, can enable greater opportunity or it can simply evoke the thrill of movement itself. Like the act, the story of passing contains radical, even revolutionary elements, as it can draw attention to the experience of oppression, to discrimination or to the desire to live as your own opposite. As Sirk observes in relation to melodrama, however, popular narrative must follow a conventional (ostensibly safe) formula.

Likewise, the passing story might be said to fail as a revolutionary or subversive plot in that it ultimately eliminates he or she whose crossing threatens the status quo. On the other hand-as in Sirk's indication that there is more than one way of reading a formulaic structure - passing stories also contain structural elements that can be too easily ignored or passed over. For instance, while the passing story ultimately eliminates transgression with a 'happy' (ideologically safe or predictable) ending, it also often includes the spectre of other, often minor, passers whose trajectories are not always fully narrated or explained.

10 Ibid., p. 140.

11 Rooney, Monique 2001, 'Grave endings: the representation of passing', Australian Humanities Review, September, viewed 28 February 2010, <http://www.australianhumanitiesreview.org/archive/IssueSeptember-2001/rooney2.html>

12 See Sollors, Werner 1997, Neither Black Nor White Yet Both: Thematic explorations of interracial literature, Oxford University Press, Oxford, p. 247. 
This is the case in Nella Larsen's canonical novella Passing (1929), in which the racial passer, Clare Kendry, returns to the black community from which she has crossed over to live as a white woman. Clare's return poses a threat. Having crossed the colour line, she has been living in virtual exile from friends and family. Her return therefore flirts with exposure itself (the narration or representation of passing) and this poses a particular danger to Irene Redfield, her friend who enjoys the thrill of occasional passing (the novel opens with Irene drinking tea in Chicago's exclusive Drayton Hotel - a place restricted to whites only). Following the formula of passing narratives, Clare is killed off in the denouement. While there has been much commentary on what Clare's death means vis-a-vis race politics, readers have been less interested in Irene's unexplained fate and the importance of her survival. To notice Irene's passing survival is to attend to the how of the narrative. It is to remember that Irene plays an essential role as a temporary passer and, importantly, it is to see the essence of her structural role as the narrative focaliser whose recognition of Clare facilitates the story.

This narrative structure - which elucidates the role of the double (the reader and the writer) in storytelling - forms the basis of Sirk's Imitation of Life. Sirk's 1959 film is based on a 1933 novel of the same name, written by Fannie Hurst, whose subsequent screenplay was directed by John Stahl for the original, 1934 film. It was producer, Ross Hunter's, idea to remake the original film, one that Sirk found overly sentimental and out of step with the changing race politics of the 1950s. While he retains the original story of an African-American girl who attempts to pass for white, Sirk changes some plot details for a 1950s context and undercuts the melodramatic story with ironic humour and self-conscious filmic twists that can be read as a commentary on 1950s race and cinema culture. Sirk's version was released only two years after a racist code was overturned that banned interracial romance on screen. Here the relation between the passer as onscreen character and passer as off-screen actor speaks to a history of racial appropriation in Hollywood history (white actors presenting as blacks). ${ }^{13}$ Susan Kohner - the daughter of Mexican actress Lupita Tovar and Hollywood producer Paul Kohner-plays the mixed-race daughter (Sarah Jane Johnson). In performing this part, Kohner effectively passes as an African American who passes for white. Of course, the audience does not necessarily know that Kohner is not black. The question of whether or not audiences recognise this extradiegetic passing narrative is partly the point. Cast as a white-looking passer who is cast as the daughter of an inescapably black-looking mother (Juanita

13 For a comprehensive discussion of Hollywood's ban on interracial romance on screen, see Courtney, Susan 1998, 'Picturizing race: Hollywood's censorship of miscegenation and production of racial visibility through Imitation of Life', Genders, vol. 27, viewed 4 February 2010, <http://www.genders.org/g27/g27_pr.html> 
Moore as Annie Johnson), Kohner performs a masquerade of a masquerade. To unmask her passing performance, in other words, is to find another mask, another passing role.

In these ways, Sirk's film draws attention to the industrial processes of filmmaking - particularly the way in which images simulate and reproduce but can also distort real life - and one of the ways it does this is through its reflection on the role of actors. For instance, when Sirk says that 'Susan Kohner, a complete beginner in pictures, steps forward putting Turner and [John] Gavin in the shade', he is deliberately subverting the Hollywood star system and its maintenance of power and race hierarchies. His argument, quoted earlier, that Sarah Jane's role is the only 'real' aspect of the film also speaks to this. As Imitation's restless shape-shifter, who travels further (metaphorically and literally) than any other member of her mixed-race family, Sarah Jane plays a crucial role in articulating the film's unresolved tensions (racial, sexual, familial, generic, cinematic). As already stated, Sirk identified strongly with this figure and she could also be understood as a key figure in his subversion of accepted ideologies - the raison d'etre of his melodramatic oeuvre. What then is to be made of his dismissal of Lana Turner's role as Lora Meredith? Stating that the film 'could not have been sold without Lana Turner', ${ }^{14}$ Sirk argued that she had only one good line in the film-

when she says 'No!', when the negro woman [her maid] dies. This is the best thing Lana Turner does, saying that 'No!' - because she is nothing. She was very good in Imitation of Life, because she wasn't supposed to be a successful actress, or a particularly good one, and so she comes out rather well, plain minded. All her life is tied up with this negro woman, about whom she really knows nothing; and so when the negro woman dies, Lana is left completely empty. ${ }^{15}$

It is worth remembering that this view of Turner is placed in the context of Sirk's stated views about the necessarily formulaic, melodramatic form. Given his love of the playful, Euripidean dramatist who is watching on with a twinkle in his eye, it seems foolhardy to take Sirk's dismissive words here at face value. In other parts of the interview, Sirk also states that through film-making he has learned to trust images rather than words. 'The camera sees with its own eye,' he says to Halliday, 'it sees things the human eye does not detect.' ${ }^{16}$ Sirk's belief in the veracity of images - and the mechanics of production-also undercut

14 Halliday, Sirk on Sirk, p. 153.

15 Ibid., p. 153.

16 Ibid., p. 99. 
pejorative remarks he made about his producer, Ross Hunter, to suggest that both the ironic and the melodramatic (the imitative) aspects of the film were essential to its overall meaning.

'I was hampered by Ross Hunter,' Sirk claims in the Halliday interview. ${ }^{17}$ Likewise, the cultish focus on Sirk (interest in Sirk has grown since the 1970s, alongside the rise of film studies as a discipline $)^{18}$ has tended to overshadow Hunter's importance as producer of Sirk's most famous films. This is despite the fact that, at the peak of Hunter's career, journalists wrote about him as if he were the director of his own films. ${ }^{19}$ A producer who 'had his finger on a certain pulse in America', ${ }^{20}$ Hunter introduced Sirk to Rock Hudson, who starred in two of Sirk's most celebrated films, Magnificent Obsession and Written on the Wind. It was also Hunter who wanted Lana Turner for the role of Lora Meredith and who insisted on the 'weepie' angle: 'He was always coming to me and saying, "Doug, Doug, make them weep!".'21 Sirk's attribution of the film's most melodramatic elements to Hunter is significant given that, in the Hollywood milieu, Hunter developed, as William J. Mann has written, a reputation as a producer of 'old-style' sentimental films and light comedy. 'Critics said he was to movies,' Mann writes, 'what Liberace was to music: overblown, artificial, playing to sentiment. ${ }^{22}$ David Ehrenstein discussed Hunter's reputation in terms of his closeted homosexuality, which circulated in Hollywood as a 'singular' identity - for instance, he once publicised his intention to marry Nancy Sinatra, an 'intention that never reached fruition'. ${ }^{23}$ Hunter was making films at a time when the studios were competing with television and adapting to other cultural shifts and Mann read his living out of a closeted, gay sensibility in terms of this yearning for a bygone era. 'I don't want to hold up a mirror to life as it is,' said Hunter to an interviewer, 'I just want to show the part which is attractive.' ${ }^{24}$ In the 1997 reprint of Sirk on Sirk, however, the director makes the following, candid remark about the producer:

\footnotetext{
17 Ibid., p. 106.

18 The groundswell of critical and experimental interest in Sirk is said to begin with Jon Halliday's original published interview with the director, published in 1971. This was soon followed by a film festival and a collection of influential essays on the director: Mulvey, Laura and Willemen, Paul (eds) 1972, Douglas Sirk, Edinburgh Film Festival, Edinburgh. The latter includes an essay by Rainer Werner Fassbinder, the avant-garde director whose style is strongly influenced by Sirk. For Sirk's impact on critical film scholarship and institutionalised readings of Hollywood melodrama, see also Laura Mulvey's more recent essay, 'Social hieroglyphics: reflections on two films by Douglas Sirk' (Fetishism and Curiosity, Indiana University Press, Bloomington and Indianapolis, 1996, pp. 29-39).

19 Mann, William J. 2001, Behind the Screen: How gays and lesbians shaped Hollywood, 1910-1919, Viking, New York, p. 354.

20 Halliday, Sirk on Sirk, p. 106.

21 Ibid., p. 106.

22 Mann, Behind the Screen, p. 350.

23 Ehrenstein, David 1998, Open Secret: Gay Hollywood 1928-1998, William Morrow \& Co., New York, p. 129.

24 Ibid., p. 129.
} 
I sometimes think Ross Hunter played a part in pushing Rock towards being homosexual. At first, Rock seemed to me to lie near the middle of the sexual spectrum, but when he met up with Ross, that was it. The studio had a heck of a time trying to hide Rock's sexuality. ${ }^{25}$

Sirk's outing of a homosexual passing narrative here - one that implicates Hunter and Hudson - is in tension with the director's stated views about the way Hunter's production methods hindered his own approach. It also shed a different light on his view of Rock Hudson (and, by association, Lana Turner) as an actor who was such a Hollywood caricature that he was unable to play one of the 'split' characters that so interested Sirk. ${ }^{26}$ More importantly, it suggests that Sirk follows the antithetical method he evokes in his discussion of melodramathat is, the gap between Sirk's stated and his real meaning is also conveyed through the gap between his comments about film-making and what there is to be read in his most important film, Imitation of Life.

\section{'What is love?': Imitation as a family romance}

Recognition of Sirk's playful, double meaning thus informs my reading of Imitation's dual plot and its hybrid, generic structure. The opening credits of Imitation stage the film's marriage of sentimental 'weepie' with ironic distance. Accompanying the credits is the Imitation of Life song, which-like a Greek chorus - didactically rehearses the melodramatic plot before it has even begun:

What is love without the giving?

Without love you're only living

An imitation, an imitation of life

Skies above in flaming color,

Without love, they're so much duller

A false creation, an imitation of life. ${ }^{27}$

The words of this song introduce Sarah Jane's plight as passer - the character who, as Sirk says, chooses the artificial life when she abandons her mother to pass for white. This imitation life - a life lived without love - is presented not only through the song but through an image on screen that is 'falsely created'. As the credits roll, the audience views an image of diamonds slowly dropping to form a cluster, creating a simulation of a cellular structure (Figure 1); the image is similar to that seen when looking at a blood sample through a microscope. This reference to the microscopic, which is invisible except through a certain

\footnotetext{
Halliday, Sirk on Sirk, p. 107.

Ibid., p. 112.

Film quotes are taken from the complete film script reprinted in Fischer, Imitation of Life, p. 43.
} 
kind of lens, could be said to be 'false' in that it uncovers a world not otherwise visible to the human eye. The diamonds also look like falling drops of wateran image that perhaps pays homage to the 'weepie', the melodramatic genre in which the expensive jewel represents the commodity of female display (and Ross Hunter allegedly spent more than \$1 million on real diamonds for Lana Turner's costuming). ${ }^{28}$ Through this opening - and remembering Sirk's comments about how the camera sees what the human eye cannot - the film-makers seem to point to the inadequate function that words and images play as supplements that pass for the presence of real actors in real time.

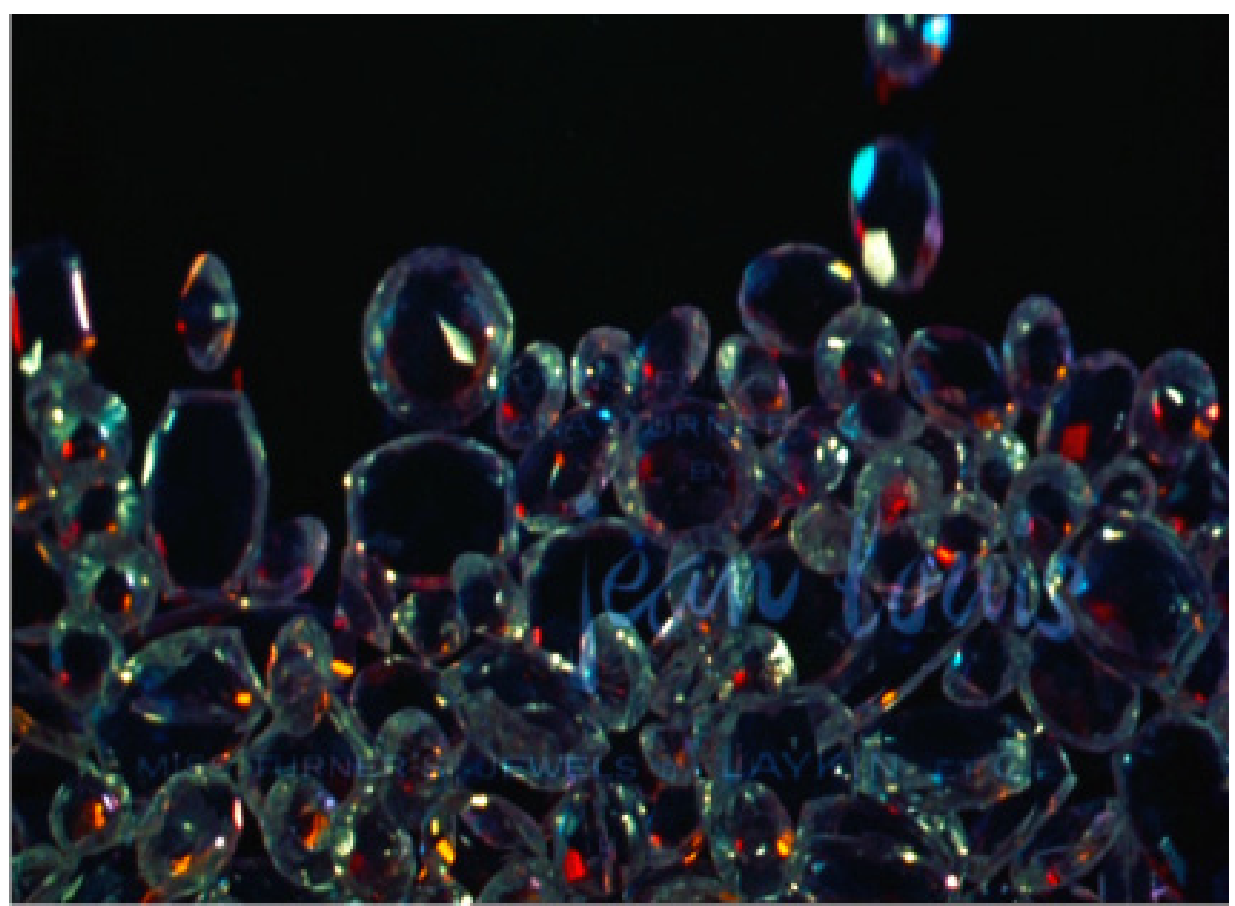

Figure. 1

The disjunction between word and image - 'the false creation', the 'imitation of life' - in the opening credits thus carries with it a sense of melancholic loss. This loss can be understood - not only in the light of Sirk's tragic experience or of Hunter's nostalgia for the past - in terms of the antithetical structure, that uneasy union of opposites, that is essential to melodrama. This antithesis is also evident in the first scene of the film, a scene that again presents the human form as a spectacle able to be distorted. After the credit sequence, there is an extreme long-shot that pans over a seascape, at the end of which is Coney Island (where a carousel turns) and a mass of anonymous bodies is viewed in the distance. The out-of-focus bodies blur against the backdrop of sand and water, like distant

28 Mann, Behind the Screen, p. 350. 
shapes in an impressionist painting (Figure 2) as the mise en scène again draws attention to the effect of the camera on its filmed object. The next shot is a close-up of movement on the boardwalk. At this point, Lana Turner enters as Lora Meredith, a woman whose ambition to be a stage actress separates her from her role as mother. The first shot of Lora is not of her face but of her legs, pictured hurrying along the boardwalk. Dissociated from the face- the site par excellence of emotional melodrama - the legs stand in for both sexuality and everyday domesticity: two shopping baskets brush up against sheer stockings as the camera again fragments the human subject through representation of the bodily part.

This inverse sequence of legs before face is also appropriate for the introduction of Lana Turner as Lora Meredith who, as Richard Dyer writes, is celebrated not so much for her face as for her 'sexy-ordinary' persona as the 1950s 'sweater girl' ${ }^{29}$ When the first piece of dialogue is heard, it is also dissociated from the part that speaks it, as the camera remains focused on the legs and a frantic voice is heard calling out 'Susie, Susie'. Panicking in her search for her lost child, who has disappeared among the swarming crowd on the beach, Lora (as many critics have noted) is pictured here as castrated mother who is separated from her loved one. ${ }^{30}$

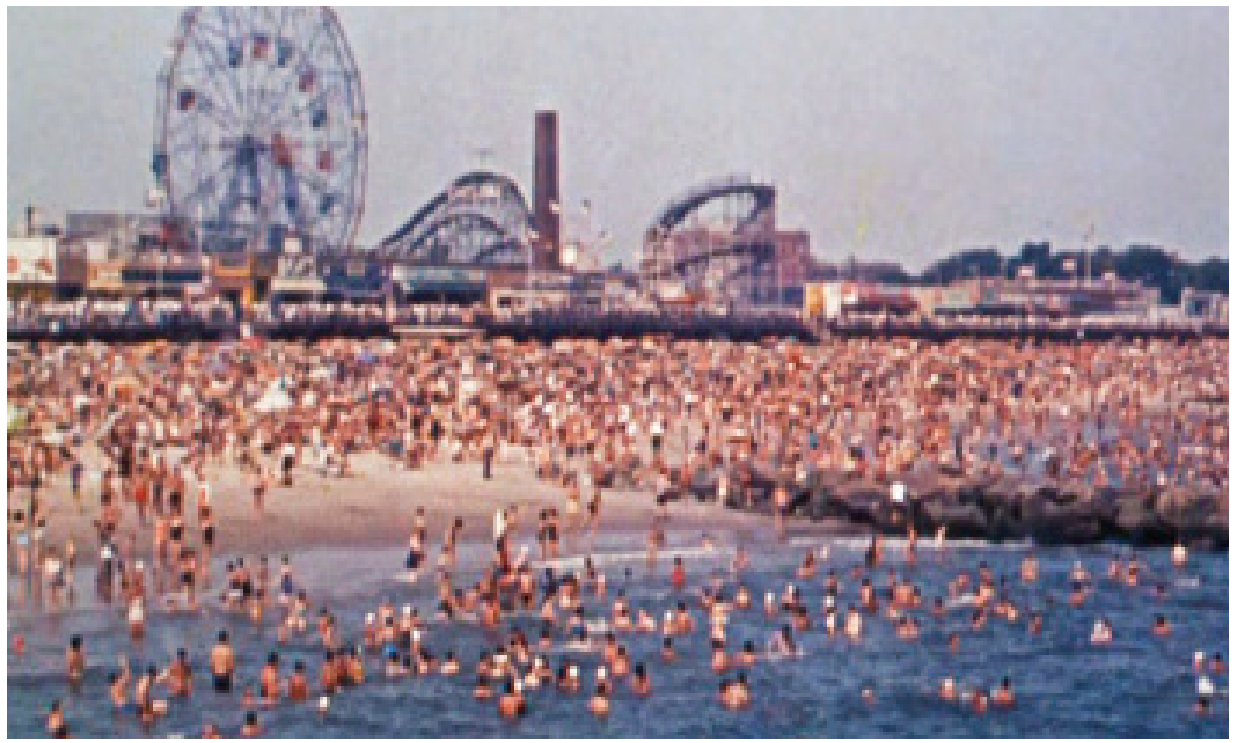

Figure.2

29 Dyer, Richard 1991, 'Lana: four films of Lana Turner', in Marcia Landy (ed.), Imitations of Life, Wayne State University Press, Detroit, Ill., p. 411. For more on Lana Turner's costuming, see Affron, Charles 1991, 'Performing performing: irony and affect', in Fischer, Imitation of Life, pp. 207-15.

30 For an exemplary reading of the film as an examination of the costs of motherhood, see Marina Heung's "'What's the matter with Sarah Jane": daughters and mothers in Douglas Sirk's Imitation of Life' in Fischer, 
The next scene stages the reconciliation between white mother and child as Lora meets Annie Johnson, who has found the child, on the crowded beach pictured in the opening. It is in this scene that Lora first meets Sarah Jane and is the first to (mis)read her white appearance. Lora not only assumes Sarah Jane is a white child, she assumes Annie is her nanny rather than her mother. In this primal scene, Lora is like the blinded father of the Oedipal drama. She stereotypes the black woman as only supplementary mother who rears children for the white woman (and by extension for the white race) only. At the same time, Lora sets in chain a repetition of the Oedipal drama - in which she plays a symbolic rolewhen she agrees to take Annie and Sarah Jane into her home.

This primal drama continues into the next sequence. While Lora and Annie talk-sharing their brief, personal histories-Sarah Jane and Susie race recklessly around the beach in joyful play. They overturn umbrellas and disclose private moments (including a pair of lovers entwined in one another's arms) to the glare of the public and cinematic gaze. Here, the audience is reminded of the liminality of objects - the umbrella, like the passer's skin, which keeps distinctions between private and public, interior and exterior in place. When the children place a beer can on a sleeping man's bloated stomach, they laugh as the can floats up and down in comical synchronisation with the man's breathing (Figure 3). The violence the man unleashes when he wakes to find he is the object of a joke seems suddenly out of place in the leisurely beach setting: 'I oughta knock your blocks off.' Meanwhile, Steve Archer (a photographer and Lora's love interest, played by John Gavin), who has been trailing and taking snaps of the glamorous mother since she first appeared on the boardwalk, captures the moment (the man with the beer can). In another moment of misrecognition, the woken man assumes Steve is the children's father and abuses him for not keeping 'these brats in line'. Embracing the moment as an opportunity to become romantically involved, Steve immediately falls into a conventional role by blaming the mother for her lack of attention: 'No use talking to her- she not only spoils them, she goes around losing them.' If Sarah Jane's desire to pass is - as Sirk claims in the interview with Halliday - an imitation of life then it is one that is inaugurated by Lora Meredith. Like the symbolic white father who is blind to his part in the plot, Lora misrecognises the black child as white and the photographer (arguably a stand-in for the director, Sirk, himself) blames the white woman for this misreading. 


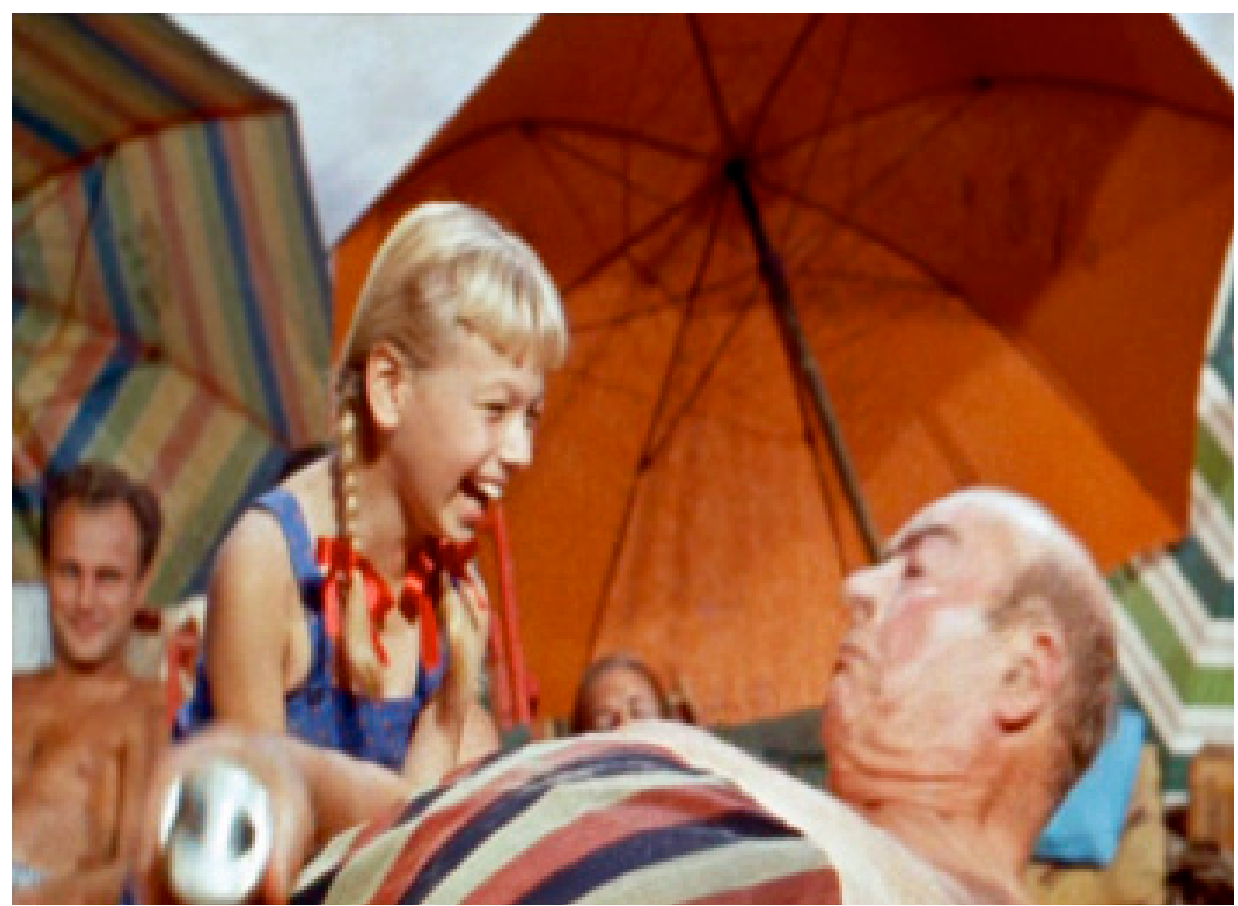

Figure. 3

The film's representation of passing via the Oedipal family romance also occurs in a scene in which Annie witnesses her daughter passing for white. When she discovers that Sarah Jane has been lying - she is not doing her job of reclassifying books at the public library-Annie tracks her down at 'Harry's club', where she is performing as a burlesque dancer. Here, the parallel between library reclassification and Sarah Jane's reinvention of herself as white relays the film's own generic inventiveness. In this scene, Annie not only sees her daughter barely clad and dancing in front of old, white men, she sees her betraying her race by passing as white. As Sarah Jane dances, she sings a song that articulates the film's Oedipal (incest) plot. The song Sarah Jane sings is about her identification with white culture as the lost father:

The loneliest word I've heard of is 'empty'

Anything empty is sad

An empty purse can make a good girl bad

You hear me dad? ${ }^{31}$

As she mimes these words, Sarah Jane performs the ritualistic moves of the striptease. The stylised performance, combined with the directness of the message, proclaims prostitution as a lack (an 'empty purse'). At the same time, the dance re-envelops the threatened exposure (Figure 6). 


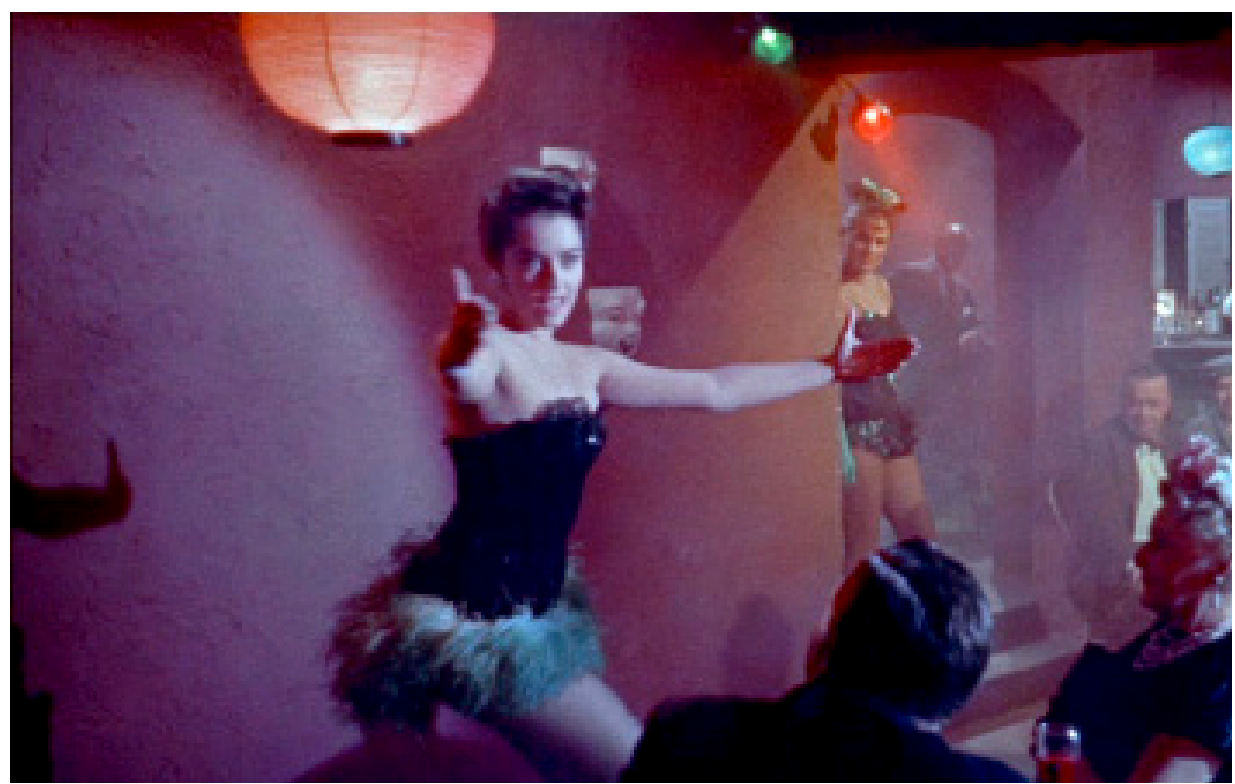

Figure. 6

In his essay on the striptease, Roland Barthes argues that the act of undressing (exposure) is invested with the fear of death. Describing the way the stripper rarely stands fully naked as she surrounds herself with props and performs a ritual, which detracts from her lack of 'hidden depth', Barthes finds that the stripper transports herself from the present into a world of romance, whether that be the 'Chinese woman equipped with an opium pipe' or 'an undulating vamp with a gigantic cigarette holder' ${ }^{32}$ Dressed in a brief black costume, wearing fishnets and a rich-green feather skirt, Sarah Jane's routine similarly covers the threatened exposure. Her sexuality is here in marked contrast with Lora's, who, at this stage in the drama, has succeeded in becoming a stage actress and has been shown, in the previous sequence, on a pastoral stage in a Little Bo Peep outfit. In both scenes, Sarah Jane's and Lora's theatrical roles are triangulated through Annie, who is pictured on the sidelines, watching Lora as well as Sarah Jane on stage. In the scene in which Annie watches Sarah Jane's passing act, the exotic costume of lurid green feathers and black sequins makes a shiny contrast with Sarah Jane's white skin and black hair, as the camera moves in a triangular direction from Sarah Jane to the laughing men to the image of Annie, who is screened from Sarah Jane's view.

32 Barthes, Roland 1973, Mythologies, Translated by Annette Lavers, Paladin, St Albans, UK, p. 84. 


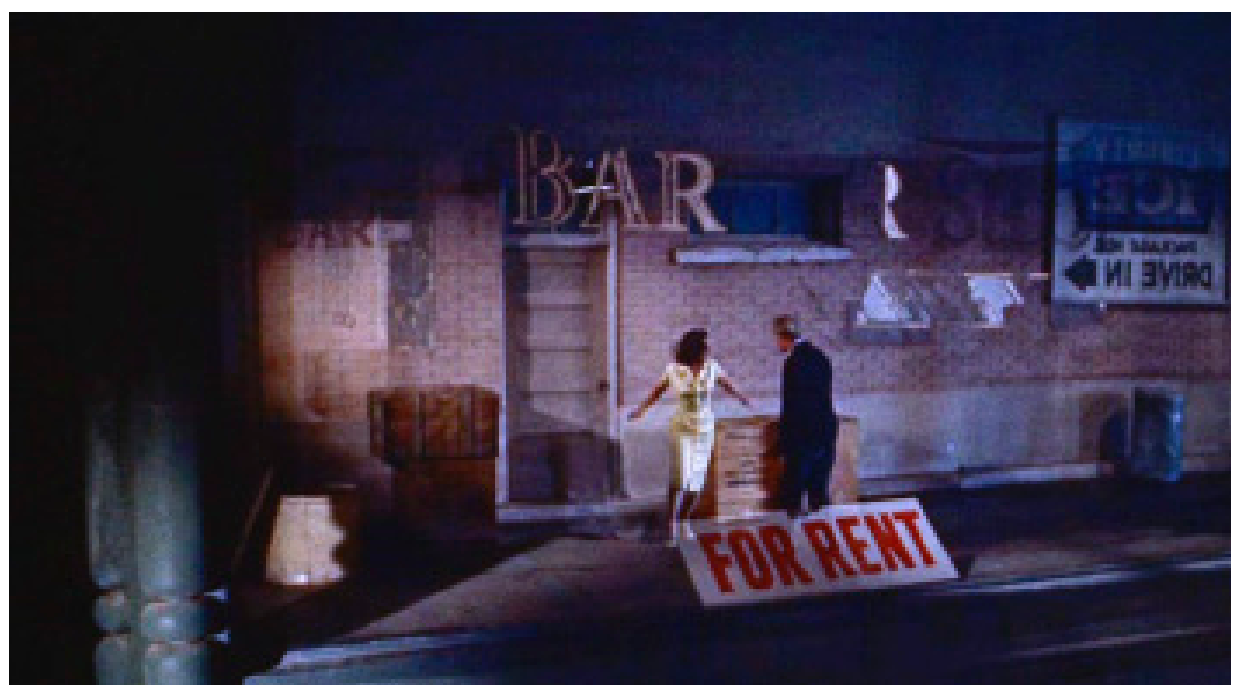

Figure. 4

While the men leer at Sarah Jane's 'empty' performance, Annie is reading Sarah Jane's disavowal of race, which is also her daughter's betrayal of her. The dispossessed black mother of American slave history has, as Hortense Spillers argues, been both marked and hidden, representing 'a locus of confounded identities', a 'meeting ground of investments and privations' ${ }^{33}$ In this scene, therefore, it is also Annie who is the 'empty purse' and whose illegitimate desire for possession - her claiming of a daughter she ultimately loses - is negated through her attempt to become a spectator of her daughter's newly found identity. The 'empty purse' not only suggests the absent father who has stolen Sarah Jane - through that inaugurating misrecognition-it evokes Annie's role as unpaid servant to her mistress, Lora, the substitute mother who not only grows more wealthy and famous as Annie sickens and grows old but who remothers Sarah Jane after Annie's death.

In tension with this drama of dispossession - in which Annie's only subject position is as the 'real' or authentic but disempowered mother-is another sequence that suggests her bond with Lora. The sequence begins with Sarah Jane waiting for her white boyfriend, Frankie, as she attempts to pass in a potentially transgressive scene of miscegenation. As stated earlier, Hollywood had only recently changed a code that banned any screening of sexual contact between black and white. In the scene opening, Sarah Jane waits outside a shop, where the sign 'For rent', clearly posted in the window, aligns her passing act with prostitution. When Frankie arrives, he aggressively confronts her about

33 Spillers, Hortense 1987, 'Mama's baby, Papa's maybe: an American grammar book', Diacritics, vol. 17, no. 2 (Summer), p. 384. 
her 'black' mother. The mirroring of Sarah Jane's desperate face-it is shown in the reflection of the shop window-connects her transgressive passing act with the filmic theme of imitation (Figure 4). The closing image of Sarah Jane is of her lying deserted in a pool of water, having been beaten by Frankie. This is accompanied by the loud, chaotic sounds of jazz music to suggest that miscegenation - a tragic meeting between black and white-exposes only primal violence.

This scene of heterosexual miscegenation as violence, which is punctuated by Sarah Jane's guttural screams, is immediately followed by a scene in which Lora expresses pleasure in a moment of physical indulgence with Annie. Richard Dyer observes that, as Lora's success and wealth increase, she is costumed in a way that accentuates her hardness (remembering, too, that Sirk refers to her in interview as one of a number of 'immovable' characters/actors). ${ }^{34}$ Dyer argues that, in contrast with an actor such as Judy Garland, 'who hangs on her acting partner's every word', 'Turner's beautifully made up face moves very little and she does not even always look at her partner'. The 'clear cut edges' and 'geometrical patterns' of her costuming in the second half of the film reinforce this mannequin-like quality. ${ }^{35}$ As she reclines on a sofa and chats to Annie, however, she becomes for a moment a tactile body ('Mm, that felt so good!'). This scene - in which the bond between Annie and Lora passes as nonthreatening sentimentality and maternal concern - seems to partially recover the brutal violence of the previous scene in which Sarah Jane's masquerade is exposed. Here, Lora and Annie talk to one another knowingly about their children but they also stumble unconsciously over their misread needs. The conversation ends, however, with Lora again misunderstanding Annie's needs. Like the scene between Sarah Jane and Frankie, the exchange between Annie and Lora involves commodification as Lora tells Annie she will be looked after:

Annie: The years are flyin'. I'm getting' old.

Lora: You never sounded so solemn before. Don't you feel well, Annie? Annie: Oh, just a little tired.

Lora: Do you need anything? Any money?

Annie: No, Miss Lora. Thanks to you, I'm well fixed...I've plenty to send Sarah Jane to college, and something to set aside for her, and enough for my funeral.

Lora: Oh Annie, that funeral again. ${ }^{36}$

34 Halliday, Sirk on Sirk, p. 112

35 Dyer, 'Lana', pp. 424-5.

36 Fischer, Imitation of Life, p. 120. 


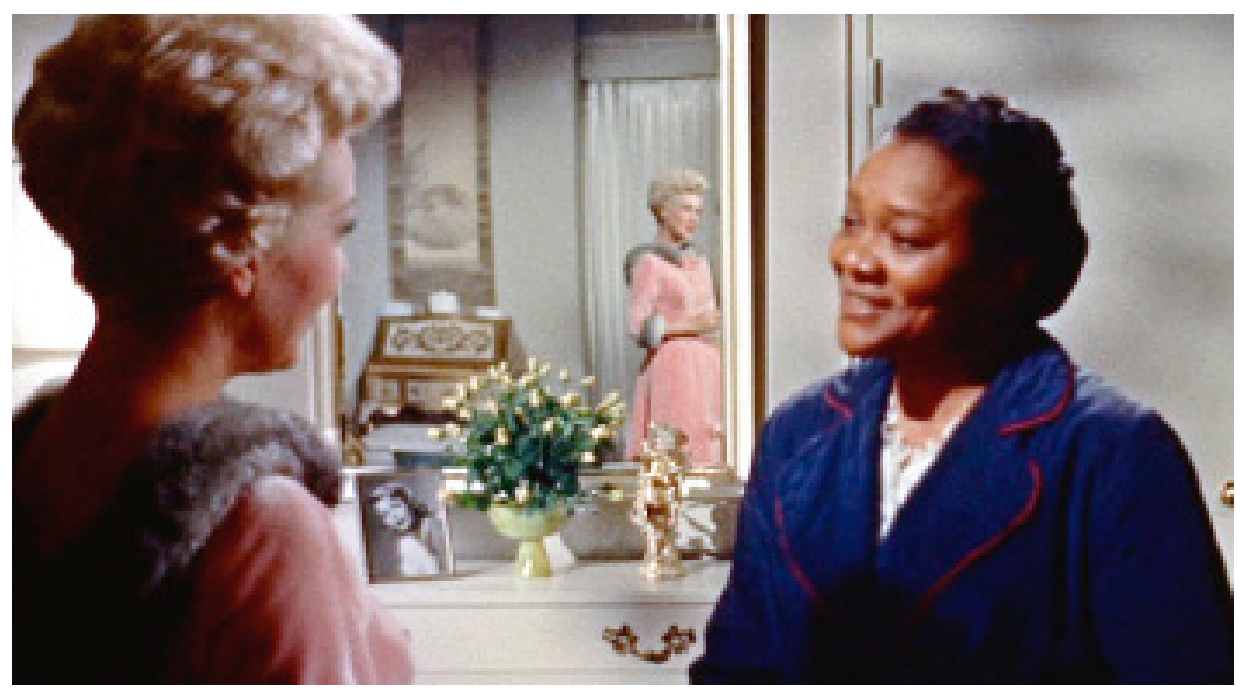

Figure. 5

Annie's death is, of course, the one factor of her life that 'Miss Lora' cannot own or control. As Annie mentions her impending death-and in a direct parallel with the previous mirroring of Sarah Jane as she is exposed by her lover-Lora's image is shown in the mirror. This image of Lora, which replaces a direct image of her response to Annie, seems to perform Lora's inability to recognise one of Annie's few stated desires. Annie's desire, in turn, is directed not towards Lora but to the 'judgment day' and an ostentatious funeral. The mirror image of Lora that ends this scene matches Annie's death drive as Lora's own narcissistic drive - the pursuit of her own image - is revealed to be as deathly as the prospect of losing Annie (Figure 5).

\section{Going up and up and up...}

Lora's artificial performance, and her synthetic costuming, displays the distance between her role as successful actor and Annie's role as domestic labourer. As she becomes more successful and wealthy, Lora's expensive costuming constrains her body. Through this imaging of Lora as a tightly packaged commodity, the film self-consciously refers to its own complicity in the marketing and dehumanising of the human body; it reinstates the 'imitation of life' it also wants to critique. This is evident in an early scene in which Lora models for an advertising agency selling flea powder. Lora's involuntary sneezing upsets the shoot and irritates 
the photographers who want her in a statuesque pose. The photographers frame the shot against a blank wall, screening out a nearby window through which can be seen an industrial landscape of trains and skyscrapers.

As Judith Butler argues, the film draws attention to its own industrial history through such references to photography in both the plot structure and the mise on scène. ${ }^{37}$ This self-referential attention to cinema's own production processes also enables an exploration of the movement of the commodity (including the star as marketable object) in late industrial society. A good example of this is in another early scene when Lora rejects Steve (the photographer on the beach) and his marriage proposal. When Steve accuses her of selfishly following an unreal dream, Lora responds by attacking his career as a photographer, characterising it as unambitious and mechanical. She refers back to the earlier scene on the beach:

What's a snapshot of a disgusting old man with a beer can on his belly? Is that your idea of achieving something? Is a beer can real? Going up and down up and down! Well I'm going up and up and up and nobody's going to pull me down! $!^{38}$

If the photograph is a snapshot - a frozen moment of real life - it is described here as if the subject is still breathing and moving within the frame: 'going up and down up and down.' Of course, the irony here is that Lora is herself a filmed object and subject to the mechanical, sequential passage of the movementimage. Lora is blind to her place in the contiguous flow of frozen images that enables her own succession to fame. Obsessed with her mirror image, Lora cannot see how her performance on stage and screen commodifies, mechanises and constrains her life. When Lora insists on her own ascension ('I'm going up and up and up'), she repeats the symbolic role of the father in the Oedipal romance - a figure whose symbolic power allows his detachment from the scene of familial construction. Yet, even this star actor-Imitation of Life seems to suggest - is no more than a passing object.

In contrast with Lora's blindness to her own image production, Sarah Jane and Annie come together in a final scene of momentary recognition. This moment is, however, as deathly for Annie as her funeral is for Sarah Jane. After Sarah Jane leaves Annie for the final time, telling her mother that she must not stand in the way of her dream of becoming white, Annie tracks her daughter down at the Moulin Rouge in Hollywood where she is passing for white and performing as a showgirl. Filmed in the real location, the shot shows Sarah Jane as a chorus girl in a burlesque routine. Although she has imitated Lora's career path, Sarah

37 Butler, Judith 1990, 'Lana's “imitation": melodramatic repetition and the gender performative', Genders, vol. 9 (Autumn), pp. 1-18.

38 Fischer, Imitation of Life, p. 83. 
Jane's is low down in the entertainment world hierarchy. She is shown reclining on a chair that moves up and down in a chain of chairs that circulates the stage - carousel-like - on a conveyor belt. As she rocks up and down in time with the other dancers, Sarah Jane manipulates a bottle in a mock pouring of champagne - an act that again imitates Lora and her hours of cocktail parties with industry associates. The carousel movement and the champagne bottle are reminders of the opening beach scene. Like the image of the man with the beer can, Sarah Jane submits herself to ritualised commodification (Figure 7).

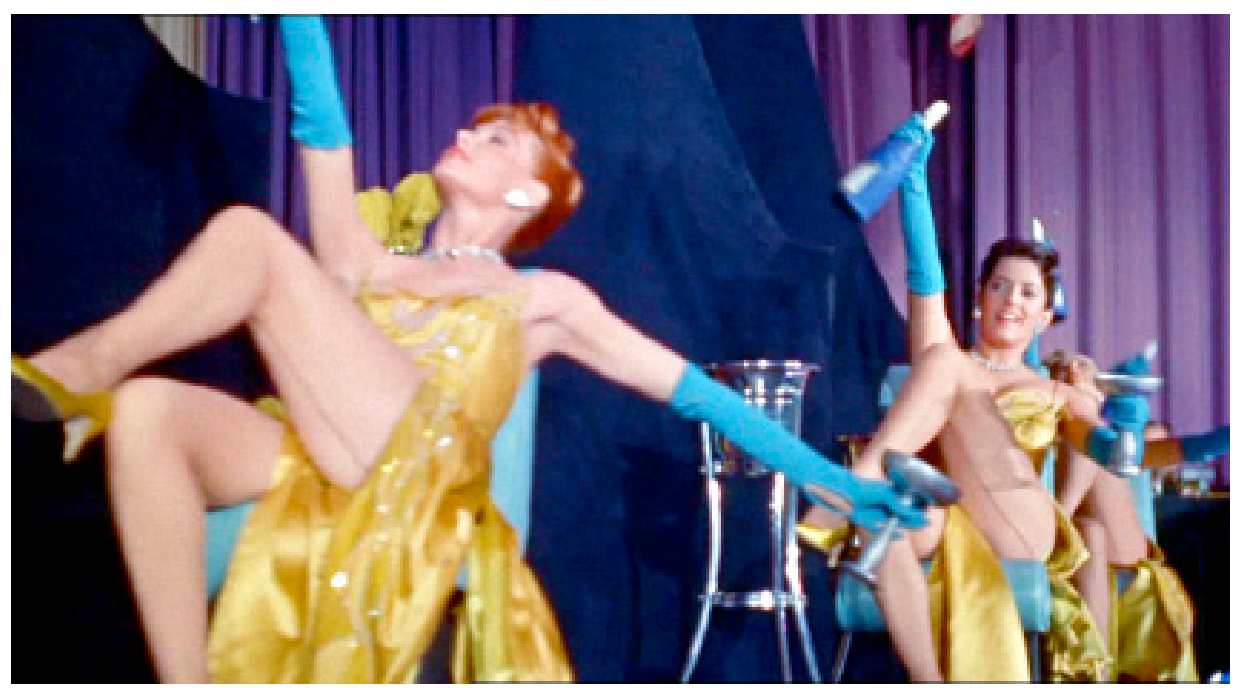

Figure. 7

Annie finds Sarah Jane in her motel room, after briefly viewing this passing act (Figure 8). Spotted watching her daughter, Annie is made to leave the auditorium as the black woman's illegitimate spectator's desire is policed in the whites-only club. In this context, Annie's final words to a protesting Sarah Jane - who again requests that she leave and never try to find her again - are disarming: 'I'll only stay a minute. I just want to look at you. That's why I came. ${ }^{39}$

The desire 'to look' at Sarah Jane is almost illicit here. It articulates the older woman's narcissistic desire to see her own reproduction. This is, however, the scene in which Annie also must recognise her daughter's betrayal of her and her race. Courageously, however, Annie refuses to concede that race is her truth when she herself puts on a performance for her daughter's sake.

When Sarah Jane's white friend interrupts their last, intimate moment, Annie puts on her most servile voice and tells her that she is 'Miss Linda's' mammy. It is Annie's sacrificial moment that makes Sarah Jane most cognisant of her loss.

39 Ibid., p. 139. 
Imitation of Life contains an implicit critique of Lora/Lana as the commodityobject who disavows her 'cheap' objectification. As imitator of this figure, however, the passer, Sarah Jane - whose masquerade is necessarily exposedultimately faces this truth as well as the mechanics of her own crossing from life to celluloid. That is, she faces the falsity of her own self-production. Sirk's dismissal of Lana Turner as merely a 'cheap imitation' thus speaks to the mechanisms of the passing narrative as a storyline that narrates the costs of crossing over or of taking up a powerful, social position - the 'success' that Sirk believes is underpinned by échec, or failure. Through this narrative, the film contains a subversive critique of the Hollywood star system and its complicity in maintaining social hierarchies and racial distinctions.

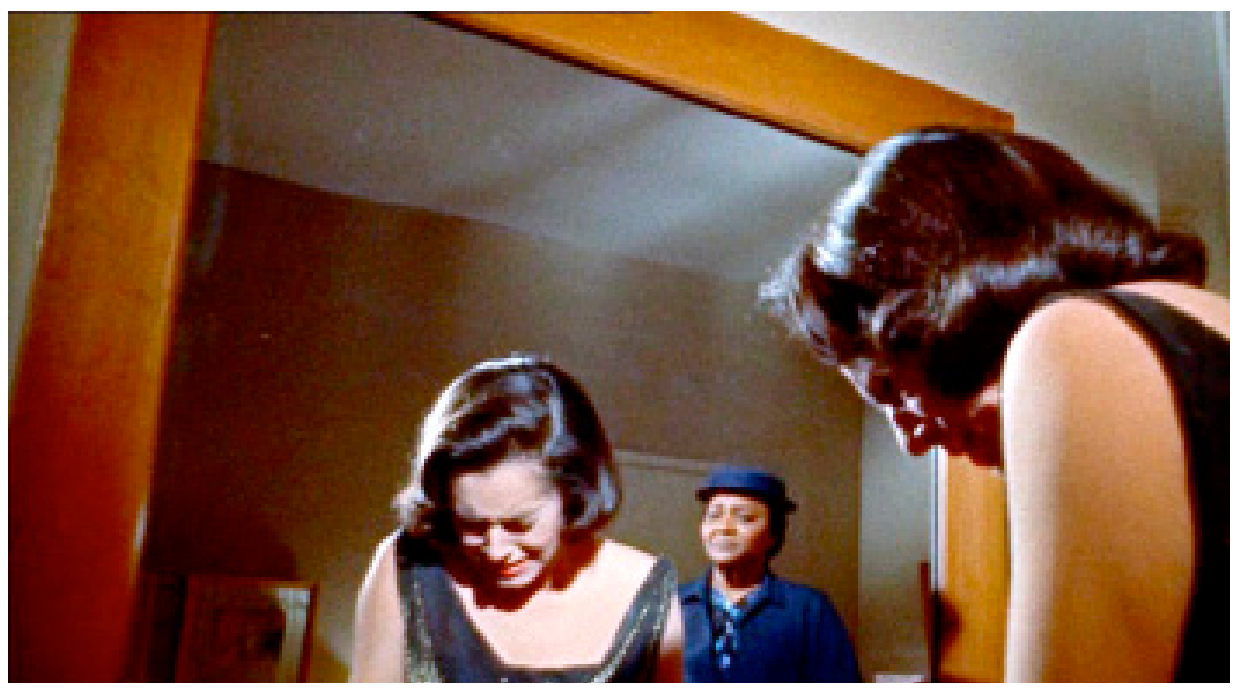

Figure. 8

All the same, it is hard not to read Sirk's criticism of Lana Turner as a cheap shot and in tension with his comments about the classic structure of melodrama, a form that he argues is based on the combination of opposites - that is, both the 'imitative' and the 'real', the formulaic and the subversive. Sirk talks in interviews about his suspicion of authoritarian or totalitarian systems as a legacy of his experience of Nazism. In the following quote, Sirk pays homage to the director's vision at the same time as he deconstructs it:

The angles are the director's thoughts. The lighting is his philosophy. Even to this extent: long before Wittgenstein, I and some of my 
contemporaries learned to distrust language as a true medium and interpreter of reality. So I learned to trust my eyes rather more than the windiness of words. ${ }^{40}$

When Sirk states that he has 'learned to trust' his eyes, he is perhaps pointing to one of the governing structures of melodrama whereby the audience believes the words of the chorus rather than what they have seen unfold on screen. In the case of Imitation, audience expectation of a happy ending is partly met when Sarah Jane renounces passing and returns to her mother, albeit too late. The final scene - a long-distance view of a funeral procession through the clouded window of an antique shop - suggests that all vision is partial, we can see only through a 'glass darkly'. Elsewhere, in interview, Sirk downplays his words and refers to the partial nature of his own vision when he states that 'the camera sees with its own eye. It sees things the human eye does not detect. And ultimately you learn to trust your camera. ${ }^{41}$ Such a comment contradicts the idea that Ross Hunter, the figure responsible for the film's production and assemblage, hindered his vision. Or, rather, it suggests that the limitation or 'blocking' of a vision - one that is too wrapped up in its own singularity or autonomy - is, literally, Sirk's échec and that this is essential to Imitation of Life's 'real' meaning.

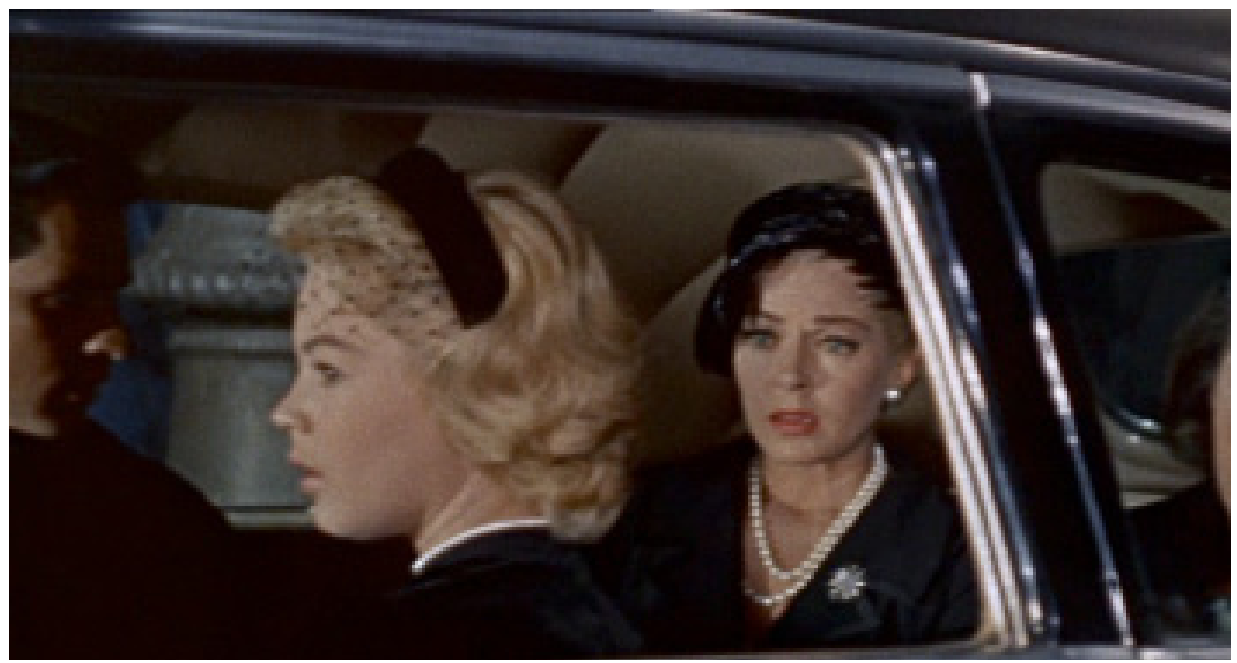

Figure. 9

The words of Imitation's chorus ('What is love without the giving/Without love you're only living') prefigure the final scene of the film. This scene stages Sarah Jane's dramatic return and renunciation of passing when she breaks through the funeral crowd and throws herself on her mother's coffin. Inconsolable, Sarah Jane grasps the coffin and cries for a black mother she has found too late: 'I wanted to come home. Now she'll never know how much I wanted to come home.' As she is pulled away by Lora, Sarah Jane joins a

40 Halliday, Sirk on Sirk, p. 40.

41 Ibid., p. 99. 
now reconfigured heterosexual family (made up of herself, Lora, Steve and Susie) as 'I wanted to come home' inverts the passer's earlier desire to escape her mother (Figure 9). The passer's 'happy ending' is, in this case, an escape from race, as it entails her reconciliation with a 'white' family. On the other hand, this ending stages the passer's surrender to a narrative formula - the sentimental 'coming home' of melodrama-which she had previously been intent on crossing. In doing so, she perhaps momentarily recognises her objectified role on the cinema screen. In this passing moment, it is the director's words, 'you can't escape who you are', that appear to lie, for they renounce the veracity of Sarah Jane's whiteness as her image, her 'false creation'. 